\title{
ECOLOGIC AND SPATIAL DISTRIBUTION OF PYRGUS OILEUS AND PYRGUS PHILETAS (LEPIDOPTERA: HESPERIIDAE) \\ AT THEIR NORTHERN DISTRIBUTIONAL LIMITS
}

\author{
By John M. Burns ${ }^{1}$ and Roy O. Kendall ${ }^{2}$
}

\section{Introduction}

In the course of his studies of the world hesperiid fauna, Evans (1937, I949, I95 I, 1952, 1953, 1955) was - as he himself stated (1949: xi) - much influenced by Mayr (1942) and therefore applied the polytypic species concept freely in postwar publications. Limited mainly to material in the British Museum (Natural History), Evans worked with fragmentary distribution data - especially for the western hemisphere - and often did not fully digest the data he had. (In view of the number of New World species to be treated and the uncertain but certainly brief time that remained to him, this is no surprise.) As a result, he frequently grouped in a single species morphologically related forms that struck him as approximately allopatric.

An extreme example of such lumping is Evans' (1953: 211) polytypic species Erynnis juvenalis embracing five subspecies - propertius (Scudder and Burgess), meridianus Bell, "plautus (Scudder and Burgess)," juvenalis (Fabricius), and clitus (Edwards) - each originally designated as a species. Detailed analyses (Burns 1960, 1964, in prep.) have shown that this transcontinental assemblage is far more accurately described as two distinct superspecies - one western and one eastern - that are sympatric in central North America from northern Arizona, New Mexico, Texas, and Oklahoma to at least the transverse Volcanic Cordillera of southcentral Mexico. Each superspecies comprises a pair of allopatric species: E. propertius and $E$. meridianus, on the one hand; and E. juvenalis (which includes clitus) and E. telemachus Burns (which succeeds plautus sensu Evans), on the other. [E. plautus (Scudder and Burgess) is really a synonym of $E$. juvenalis (Fabricius).] Submergence of these four species in a single one, in the manner of Evans, obscures rather than clarifies evolutionary relationships (see Burns 1964).

\footnotetext{
${ }^{1}$ Department of Biology, Wesleyan University, Middletown, Connecticut 06457.

${ }^{2} 135$ Vaughan Place, San Antonio, Texas 78201.

Manuscript received by the editor April 8, 1969

Published with the aid of a grant from the Museum of Comparative Zoology.
} 
A number of apparently hasty couplings of this kind have been uncritically repeated in the current synonymic list of Nearctic Rhopalocera (dos Passos 1964). Examples may be found in such genera as Erynnis, Pyrgus, Staphylus, Cogia, Amblyscirtes, and Panoquina. Thus Evans' interpretations receive empty endorsement and wider dissemination when, in fact, they require re-examination.

\section{Pyrgus oileus and $P$. philetas are separate species}

Evans (I953: 222) erroneously set Pyrgus philetas Edwards as a subspecies of Pyrgus oileus (Linnaeus), and dos Passos (1964: 19) echoed this action. MacNeill (1962: IOI) meanwhile emphasized their distinctness: "The two species are broadly sympatric in Mexico and I have taken them together at several widely separated localities on the mainland [as opposed to peninsular Baja California, where only $P$. philetas is known]." More recently, Freeman (personal communication) also has found these two forms coexisting in mainland Mexico.

Central to any taxonomic interpretation is the fact that, even with spatial and temporal coexistence, $P$. oileus and $P$. philetas differ in diverse characters of facies and morphology. These include $(I)$ colorpattern of the wings - particularly $(a)$ the ventral surface of the secondary, which, in philetas, is characteristically blanched and much less marked by sharp contrasts than it is in oileus; and also $(b)$ the dorsal surface of the male primary, which, in the proximal third of space $\mathrm{Ib}$, almost always has $\mathrm{I}$ or 2 white spots in philetas that are virtually or (in nearly all individuals) quite lacking in oileus; (2) the density, length, and orientation of white hair-like scales on the dorsal surface of the male primary - these scales are abundant, exceedingly long, and directed obliquely distad-and-caudad in oileus, but are less common, short, and directed chiefly distad (not caudad) in philetas; and (3) the genitalia in both sexes (figs. I-4). These distinguishing characters are various and complex enough that control of them by a single genetic switch mechanism is unlikely in the extreme. One may safely conclude that $P$. oileus and $P$. philetas are not polymorphic variants.

Genitalia differences are so pervasive and conspicuous, and so adequately shown in figs. I-4, as scarcely to warrant verbal comment. Yet it may be worth directing specific attention, in males (figs. I and 2), to the relative lack of spines on the valvae in oileus, the medial extension of the anterodorsal part of the distal process of the valvae in philetas, the longer saccus and adjacent longer valval articulation in oileus, the median keel and flanking concavities of the dorsal 
surface of the uncus in oileus (giving the effect of a "double scoop") as opposed to the simple convex dorsal uncus surface in philetas, the more heavily dentate gnathos in philetas, and the more delicate apex of the aedeagus in philetas; and, in females (figs. 3 and 4 ), to the highly distinctive sclerotization around the ostium bursae in the two species, the much larger wrinkled membranous sac ventral to the ostium bursae in oileus, and the very different proportions and configurations of the major sclerotization (sterigma) between the ostium bursae and the ovipositor lobes in the two species.

\section{Virtual allopatry in the United States}

Despite extensive Mexican sympatry, it appears that, in the southern United States, where these related but distinct species reach their northern distributional limits, they are practically allopatric. They seem, moreover, to be ecologically segregated $-P$. oileus to moister and typically (though not exclusively) coastal-plain environments, and $P$. philetas to drier interior ones.

The United States distribution of these species can be summarized at two levels as follows. In broad view, $P$. oileus ranges from Florida to central Texas, and P. philetas from central Texas to Arizona. On state by state inspection, $P$. oileus is clearly widespread and common in the Florida Keys and in peninsular Florida, extending as far north, at least, as Gainesville, Alachua County; and it is known also from Escambia County bordering the Gulf of Mexico in the western tip of Florida adjacent to Alabama (Kimball 1965: 52). Although it is not yet reported from either Alabama or Louisiana, Mather and Mather (1958: 93) recorded the capture of I male in 1957 at Bay St. Louis, Hancock County, Mississippi; and, in 1960, with the aid of M. and E. Roshore, they collected a total of 6 males and 4 females from four localities in Jackson County, Mississippi. Both Hancock and Jackson counties border the Gulf of Mexico. (All i I Mississippi specimens have been examined by Burns.) Pyrgus oileus occurs primarily in southern sections of east and central Texas; but a single female has been reported from as far north as North Little Rock, Arkansas (Freeman 1945: 6I). Pyrgus philetas ranges from central, southcentral, and west Texas to southern New Mexico and southern and middle Arizona. Not known from California, it conceivably could be found in the extreme southeastern part of that state.

\section{Narrow sympatry in Texas}

Since Texas is the only one of the United States in which $P$. oileus and $P$. philetas meet, we have, for several years, in the course of other 

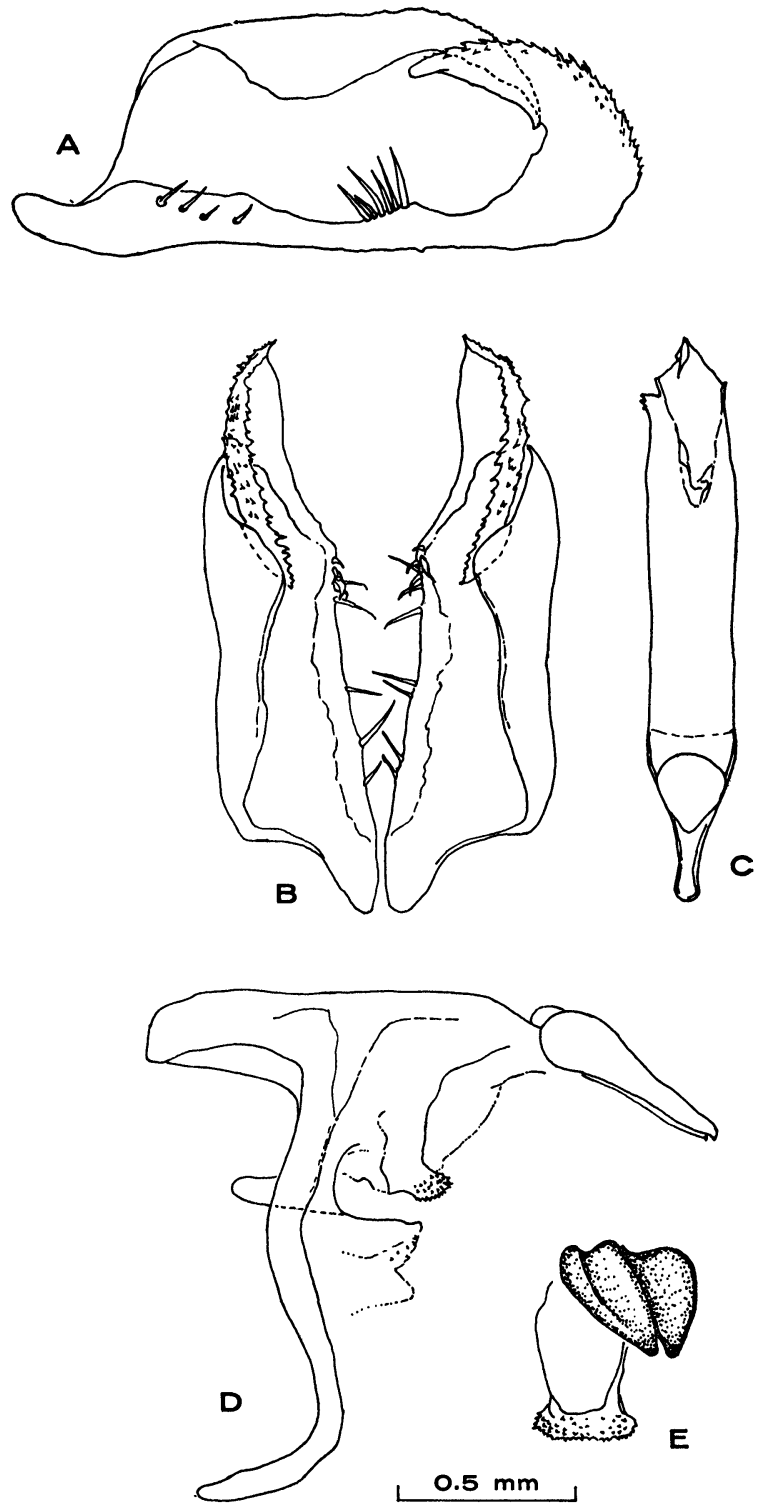

Fig. 1. Male genitalia of Pyrgus oileus. A. Medial view of right valva. B. Dorsal view of both valvae. C. Dorsal view of aedeagus. D. Left lateral view of uncus, tegumen, gnathos, vinculum, and saccus. E. Left dorsolateral view of uncus and gnathos. [A, drawn from one male, and B to E, from another; both from Houston, Harris County, Texas, VIII-121957 (J. M. and S. N. Burns).] 

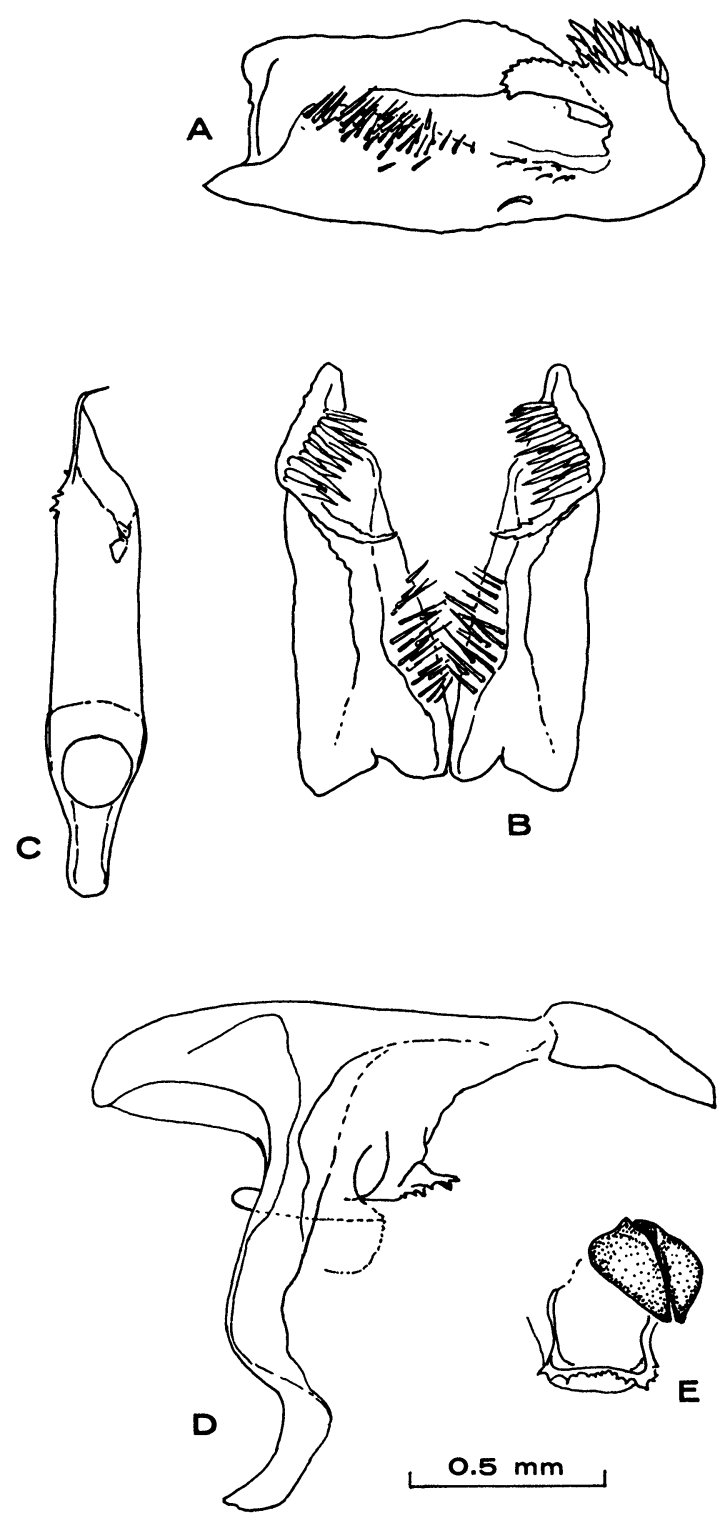

Fig. 2. Male genitalia of Pyrgus philetas. $\mathrm{A}$ to $\mathrm{E}$ as in fig. 1. [A, drawn from male from Nameless Road in NW Travis County, Texas, VI-3-1967 (J. M. Burns) ; B to E, from male from Palmetto State Park, Gonzales County, Texas, IV-6-1967 (J. M. Burns).] 


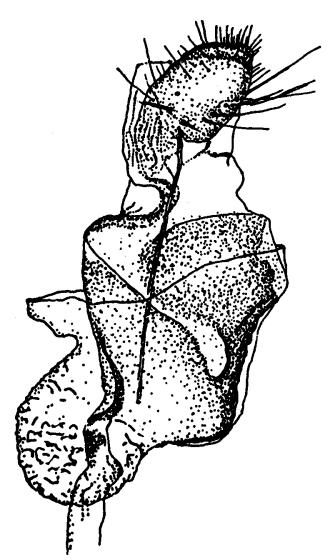

B
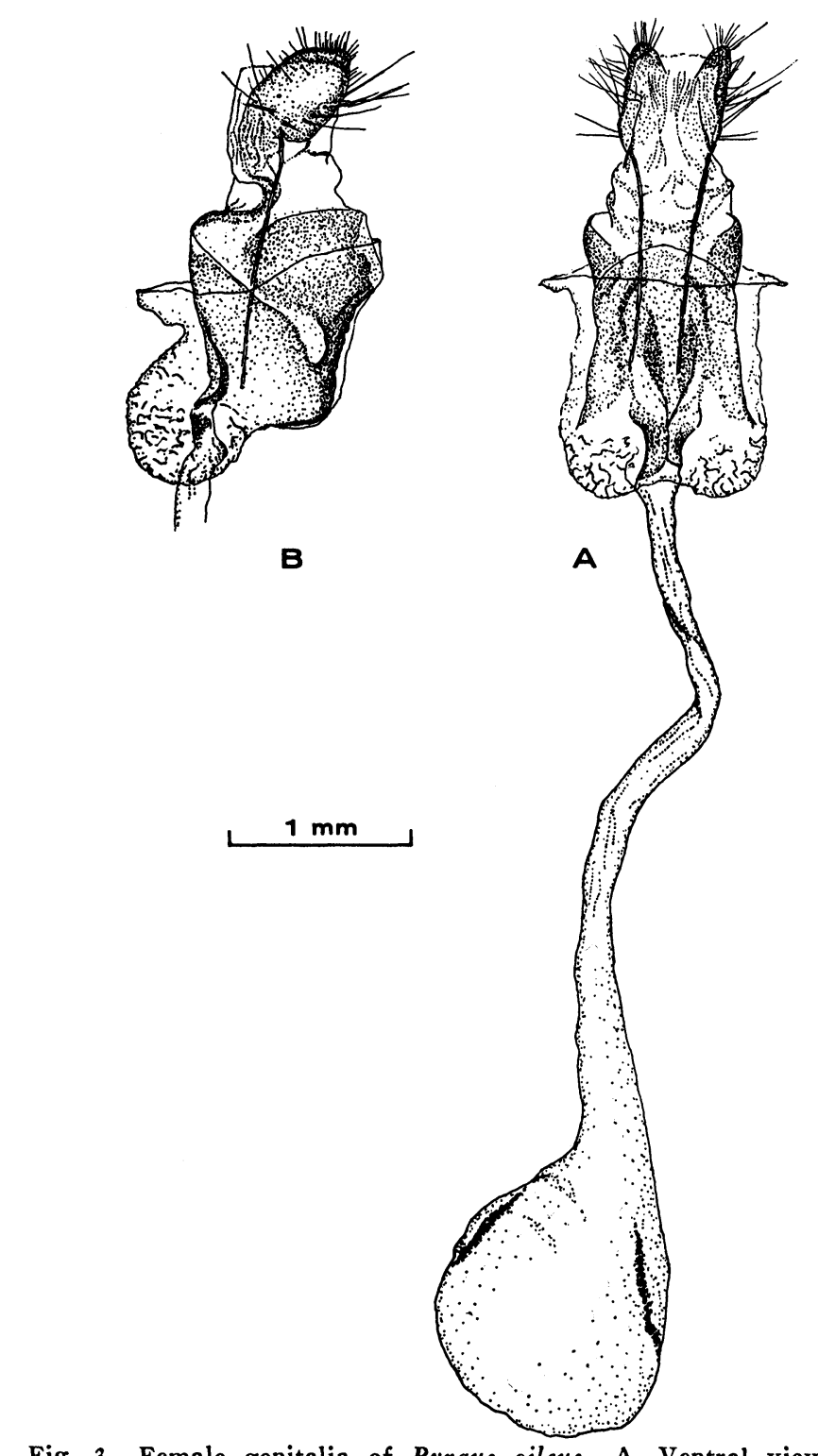

Fig. 3. Female genitalia of Pyrgus oileus. A. Ventral view of bursa copulatrix, sterigma, and ovipositor lobes. B. Right lateral view. [A and B, drawn from female from Houston, Harris County, Texas, VIII-12-1957 (J. M. and S. N. Burns).] 

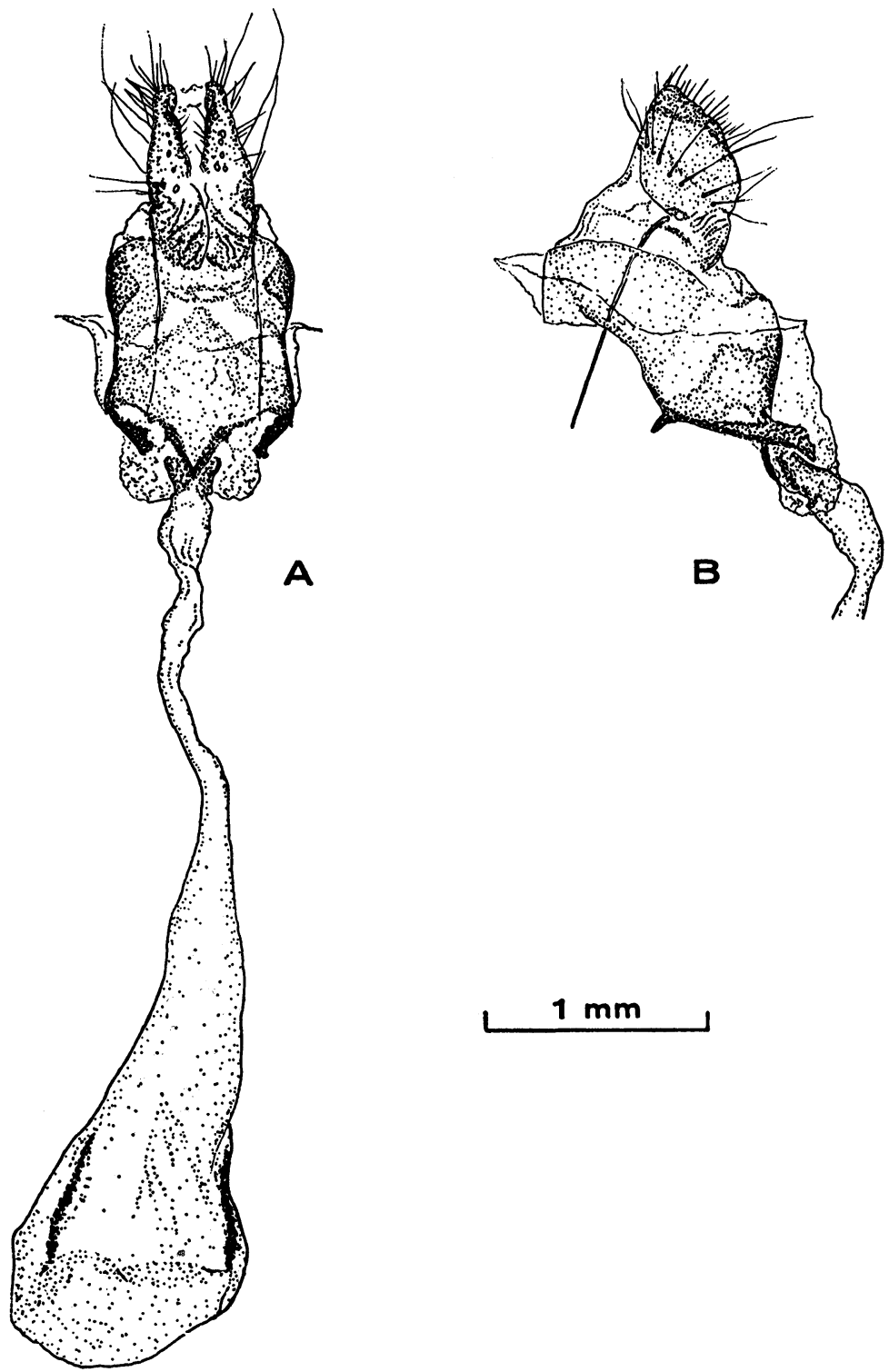

Fig. 4. Female genitalia of Pyrgus philetas. A. Ventral view of bursa copulatrix, sterigma, and ovipositor lobes. B. Left lateral view. [A and B, drawn from female from Welder Wildlife Foundation Refuge, Sinton, San Patricio County, Texas, X-13-1963 (J. W. Tilden).] 
field studies, accumulated data on the spatial distribution of these skippers in Texas and have paid special attention to the critical zone of junction. As happens for so many east-west species pairs, central Texas is where the action is (see Remington 1968 for a recent summary and general discussion). We find the two species sympatric and synchronic at several points (fig. 5) - and find no evidence whatsoever of hybridization between them (either with or without introgression).

$P$. oileus is apparently common and resident in coastal regions of Texas and sporadic at interior localities in east and eastcentral Texas. All peripheral interior records derive from only one to a few specimens caught late in the year: Dallas, I $0^{\pi}, \mathrm{IX}-\mathrm{I} 7-\mathrm{I} 948$ (H. A. Freeman); I $0^{\star}, X$ - 16 -1949 (H. A. Freeman); New Braunfels, $30^{\star}$, X-8-1967 (J. F. Doyle III, R. Jameson, M. A. Rickard); San Antonio, I $O^{\pi}, \mathrm{X}-2 \mathrm{O}-1945$ (H. A. Freeman). This, along with the lateness of the lone Arkansas record (Io, IX-10-1929, H. A. Freeman), suggests a fluctuating northern and western distributional limit that expands substantially in favorable years. The dots representing $P$. oileus in Chambers, Liberty, and Victoria counties (fig. 5) are based on larval collections reported by Bottimer (1926: 797) but are the only records (of either species) appearing in fig. 5 that are not taken from adult specimens examined by one or both of us.

Although Freeman ( 195I:2I) reported $P$. philetas only from far western (Marathon) and far southern (Laredo, Pharr) Texas, we find it resident through much of the central part of the state; and we believe that our present picture (fig. 5) is still incomplete. At middle latitudes in central Texas, the eastern distributional limit is roughly the eastern edge of the Edwards Plateau (marked by the Balcones Escarpment). Even there, however, in the vicinity of Austin, New Braunfels, and San Antonio, P. philetas is not rare; and correspondence is inexact, as evidenced by the occurrence of $P$. philetas early in the year in fresh condition in Gonzales County, 29 miles southeast of the Balcones Escarpment. Between Austin and San Antonio, the escarpment shifts rapidly from a north-south to an eastwest orientation and extends westward from San Antonio. In southcentral Texas, then, $P$. philetas departs widely from the Edwards Plateau, ranging east to Corpus Christi and south to the Rio Grande. Altogether, its eastern limit is a fairly straight line falling between the 97th and 98th meridians.

Every instance of sympatry of $P$. oileus and $P$. philetas is in central and especially southcentral Texas between the 97th and Iooth meridians. In this narrow zone we have found these species sympatric - 


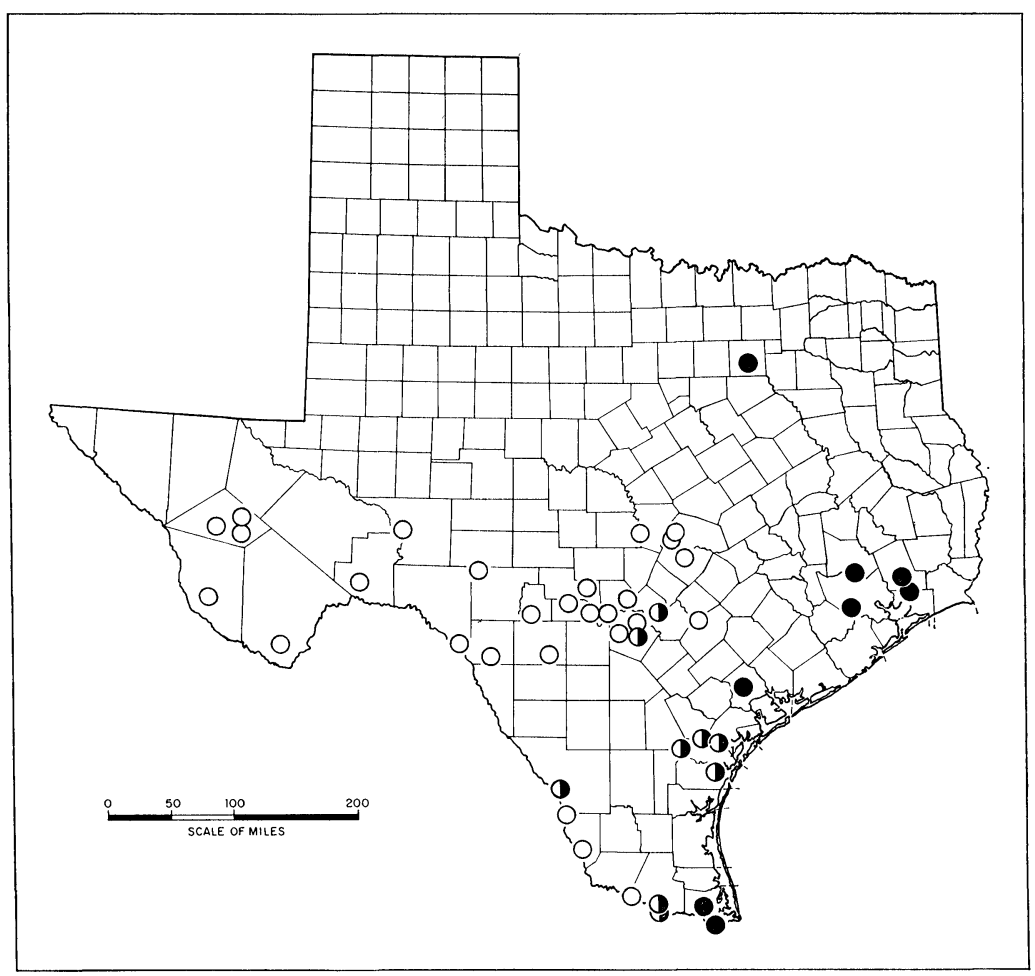

\begin{tabular}{|l|l|l|l|l|l|l|l|l|l|l|l|l|}
\hline \multicolumn{1}{c|}{} & J & F & M & A & M & J & J & A & S & O & N & D \\
\hline Pyrgus oileus & 1 & 5 & 2 & 12 & 7 & 13 & 10 & 28 & 6 & 43 & 10 & 1 \\
\hline Pyrgus philetas & 0 & 3 & 4 & 10 & 6 & 13 & 6 & 11 & 14 & 35 & 12 & 2 \\
\hline
\end{tabular}

Fig. 5. Spatial and temporal distribution of Pyrgus oileus (dots) and Pyrgus philetas (circles) in Texas. Half dots indicate known points of sympatry. The more interior and northern records of $P$. oileus probably represent transient populations (see text). Temporal distribution is crudely expressed in a month by month tally of all dated specimens examined. 
and sometimes also precisely synchronic - at New Braunfels, Comal County ( 3 oileus, 4 philetas) ; San Antonio, Bexar County ( I oileus, 24 philetas); U.S. highway I8 I x Papalote Creek, Bee County ( I oileus, I philetas); Lake Corpus Christi State Park, San Patricio County ( I oileus, 3 philetas); Welder Wildlife Foundation Refuge, San Patricio County (I 4 oileus, 6 philetas); Corpus Christi, Nueces County (2 oileus, I philetas); Pharr, Hidalgo County (9 oileus, ro philetas); Santa Ana National Wildlife Refuge, Hidalgo County (3 oileus, 3 philetas); and Laredo, Webb County (2 oileus, I philetas).

Table I summarizes by county and by sex the 156 specimens of $P$. oileus and 128 specimens of $P$. philetas that we have examined from Texas and indicates the kinds of samples on which the symbols plotted in fig. 5 are based.

Table 1. Texas specimens of Pyrgus examined.

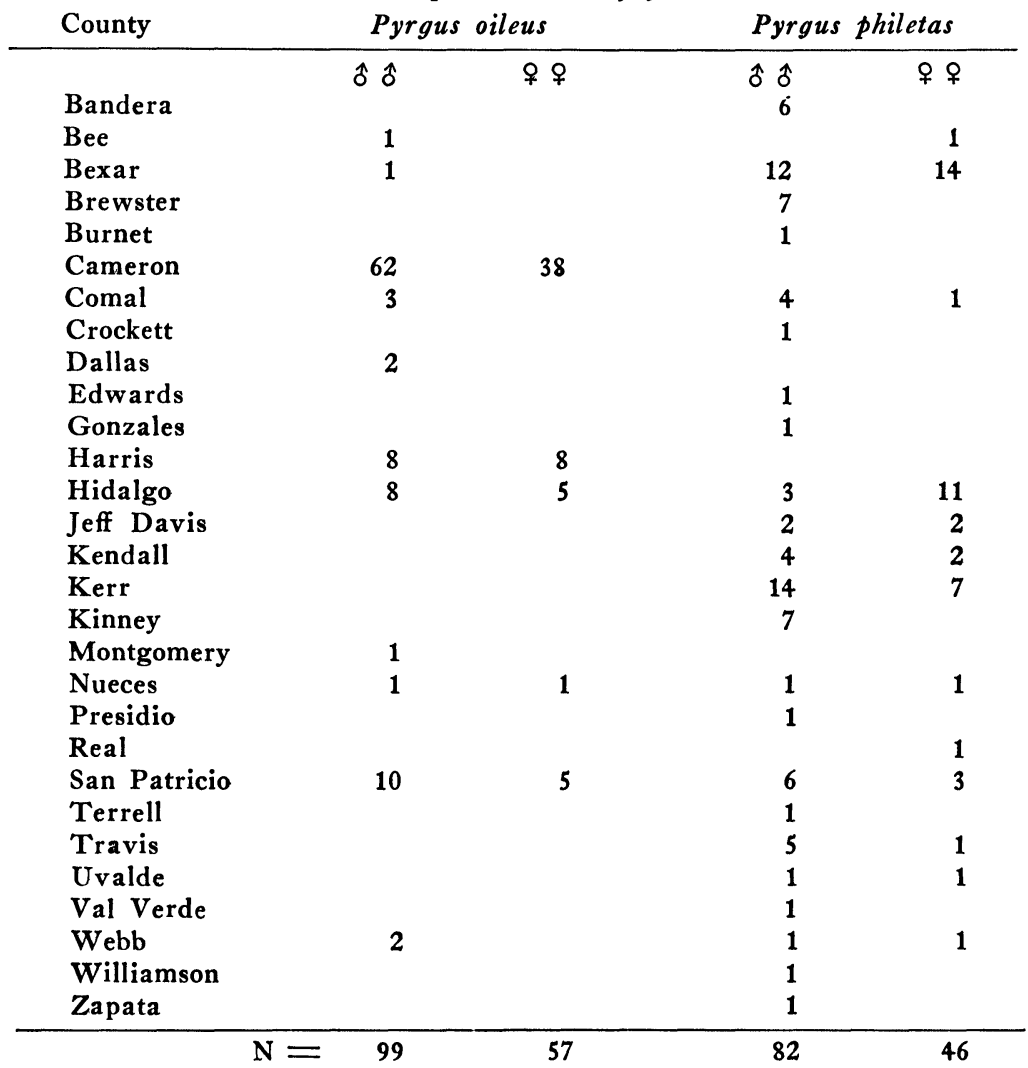


Temporal distribution in Texas

Both species are multivoltine and occur almost throughout the year (see fig. 5, bottom) wherever a suitably mild climate prevails. Even where they are sympatric, there is no temporal displacement of these two related populations.

\section{Discussion}

Reproductively isolated populations recently evolved from a common ancestor may remain allopatric, not because of competitive exclusion or the persistence of an old extrinsic barrier to distribution, but because, in the course of inevitable ecologic differentiation, they have specialized in ways that put new restrictions on their distribution. If a potential distribution-limiting factor varies abruptly in the space between them, allopatric sister populations may become finely adjusted to distinct modes of that factor and thereafter be geographically segregated by this very adaptation. Should such a condition persist, even widely diverging populations would continue to replace each other geographically like subspecies of a polytypic species or species of a superspecies, without long qualifying as either. It would be most unreasonable to insist that ecologic divergence of sister populations to a patently non-competitive, coexisting state be the sole admissible evidence of complete speciation.

The mutual geographic replacement of $P$. oileus and $P$. philetas in the United States suggests competitive exclusion and suggests that they may be more closely related than their sympatry in Mexico and their level of morphologic divergence indicate. But competitive exclusion is probably not involved. Along its eastern margin through central Texas, $P$. philetas, as noted above, stops almost on a line; yet it regularly encounters $P$. oileus only along the southern part of this line, and there there is some overlap. Rather than limiting each other, $P$. oileus and $P$. philetas are more likely limited - directly or indirectly - by humidity, an abiotic factor that decreases rapidly from east to west in central Texas. Direct limitation could stem, of course, from physiological adaptation of $P$. oileus to moister and $P$. philetas to drier conditions; indirect limitation could take the form of different larval foodplants that are, in turn, directly limited by humidity. $P$. oileus and $P$. philetas are limited northward at similar latitudes. Altogether it appears that these species, which are substantially sympatric southward, gradually sort themselves out geographically in response to humidity as they approach their northern temperature limits. 
Various explanations for the phenomenon of neatly allopatric sister species have recently been considered by, for example, Mayr (1963: 8I-82), Remington (1968), and Selander (1969: 21 5-2 I9). Mayr feels that interpretations - like the one offered here for $P$. oileus and $P$. philetas - involving differences in adaptation to sharply breaking variables of the environment, probably apply in a majority of cases. Remington and Selander, in dissimilar contexts, both emphasize interpretations involving competitive exclusion, though Selander implies that competitive exclusion may be pertinent in a minority of cases. There is general agreement that persistent allopatry of closely related species often poses intricate evolutionary problems that are hard to analyze and interpret with confidence.

\section{SUMMARY}

Pyrgus oileus and $P$. philetas, though closely related, are incontestably different species - some current opinion to the contrary notwithstanding. Sympatric in part of Mexico, these morphologically distinct, multivoltine species become allopatric toward their northern distributional limits in the southern United States. There, $P$. oileus of eastern, moister environments and $P$. philetas of western, drier environments approach each other or meet in central Texas, and overlap slightly in space (and fully in time) in southcentral Texas, without hybridizing. Although competitive exclusion could be suggested, it appears more likely that these species are limited (either directly or indirectly) by an abiotic factor, humidity.

\section{Acknowledgements}

We thank F. H. Rindge and W. D. Field for access to Pyrgus material in their care at the American Museum of Natural History and the United States National Museum, respectively; B. and K. Mather for lending Mississippi specimens of $P$. oileus, H. A. Freeman for lending peripheral Texas specimens of $P$. oileus, and J.W. Tilden for lending all specimens of $P$. oileus and $P$. philetas in his collection; and R. G. Gillmor for drawing the genitalia figures. This research was supported in part by National Science Foundation grant GB 5935 to J. M. Burns.

BotTimer, L. J.

\section{Literature Cited}

1926. Notes on some Lepidoptera from eastern Texas. J. Agr. Res. 33 : 797-819.

Burns, J. M.

1960. A new species of oak-eating Erynnis (Lepidoptera: Hesperiidae) restricted to the southern Cordillera of the United States. Wasmann J. Biol. 18: 147-160.

1964. Evolution in skipper butterflies of the genus Erynnis. Univ. California Publ. Entomol. 37: 216 pp., 1 pl. 
dos Passos, C. F.

1964. A synonymic list of the Nearctic Rhopalocera. Lepidopterists'

Evans, W. H. Soc., Mem. 1: v + 145 pp.

1937. A catalogue of the African Hesperiidae indicating the classification and nomenclature adopted in the British Museum. London: British Museum. xii +212 pp., 30 pls.

1949. A catalogue of the Hesperiidae from Europe, Asia and Australia in the British Museum (Natural History). London: British Museum. xix +502 pp., 53 pls.

1951. A catalogue of the American Hesperiidae indicating the classification and nomenclature adopted in the British Museum (Natural History). Part I. Introduction and . . . Pyrrhopyginae. London: British Museum. $x+92$ pp., pls. 1-9.

1952. A catalogue of the American Hesperiidae . . . Part II. Pyrginae. Sec. 1. London: British Museum. 178 pp., pls. 10-25.

1953. A catalogue of the American Hesperiidae . . . Part III. Pyrginae. Sec. 2. London: British Museum. 246 pp., pls. 26-53.

1955. A catalogue of the American Hesperiidae ... Part IV. Hesperiinae and Megathyminae. London: British Museum. 499 pp., pls. 54-88.

Freeman, H. A.

1945. The Hesperiidae (Lepidoptera) of Arkansas. Field \& Lab. 13: 60-64.

1951. Ecological and systematic study of the Hesperioidea of Texas (Lepidoptera, Rhopalocera, Hesperioidea). Southern Methodist Univ. Stud., 6: $67 \mathrm{pp}$. Kimball, C. P.

1965. Arthropods of Florida and neighboring land areas. Vol. 1. The Lepidoptera of Florida. Gainesville: Florida Dept. Agr., Div. Plant Industry. 363 pp., 26 pls.

MacNeill, C. D.

1962. A preliminary report on the Hesperiidae of Baja California (Lepidoptera). Proc. California Acad. Sci.,(4) 30: 91-116.

MATher, B. AND K. MATHER

1958. The butterflies of Mississippi. Tulane Stud. Zool. 6: 63-109.

MAYR, E.

1942. Systematics and the origin of species. New York: Columbia Univ. Press. xiv +334 pp.

1963. Animal species and evolution. Cambridge: Belknap Press of Harvard Univ. Press. xiv +797 pp.

Remington, C L.

1968. Suture-zones of hybrid interaction between recently joined biotas. In Th. Dobzhansky, M. K. Hecht, and W. C. Steere (eds.), Evolutionary biology, vol. 2. New York: Appleton-CenturyCrofts. pp. 321-428.

SELANDER, R. K.

1969. The ecological aspects of the systematics of animals. In Systematic biology. Washington: National Academy of Sciences. Publ. 1692. pp. 213-239. 

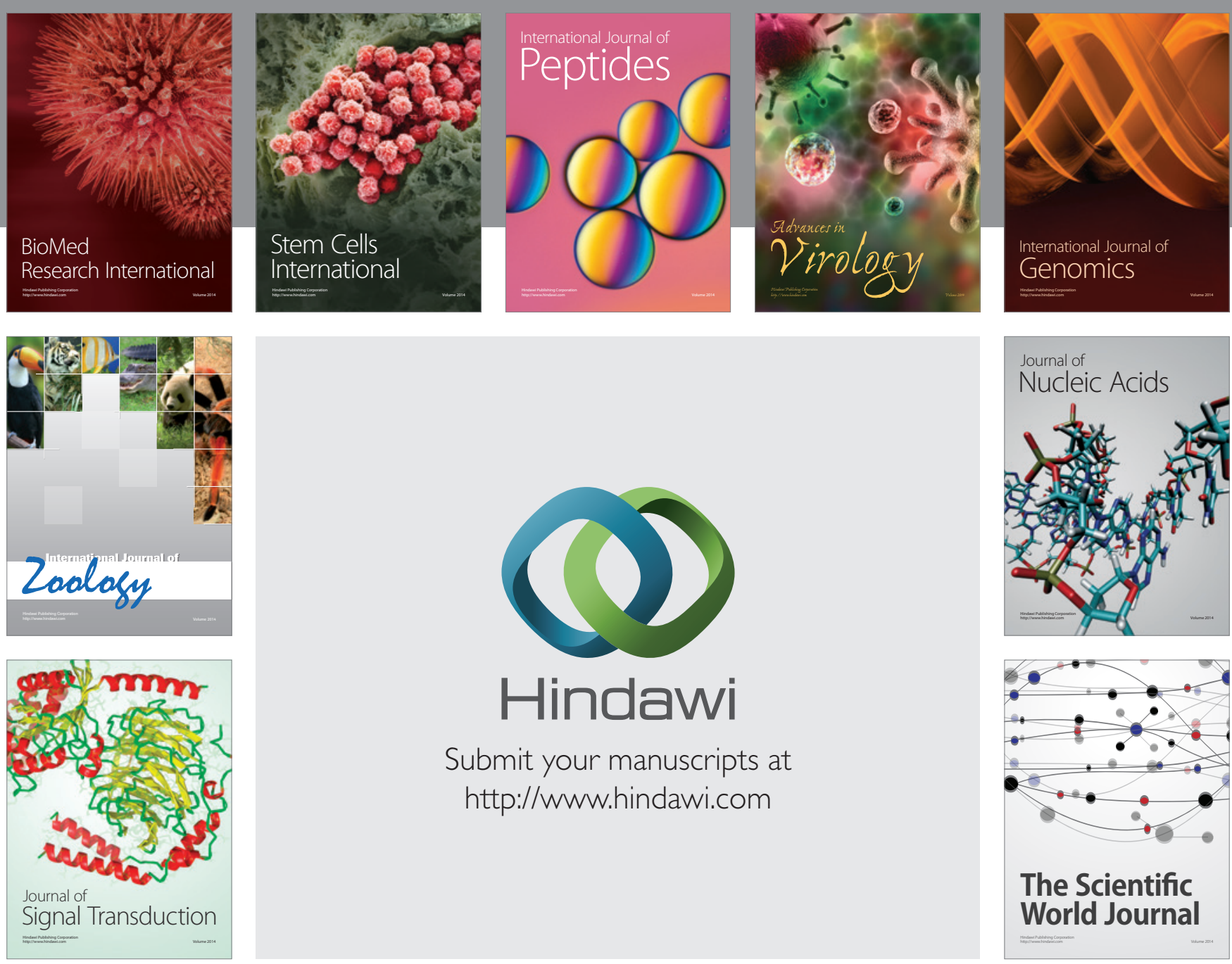

Submit your manuscripts at

http://www.hindawi.com
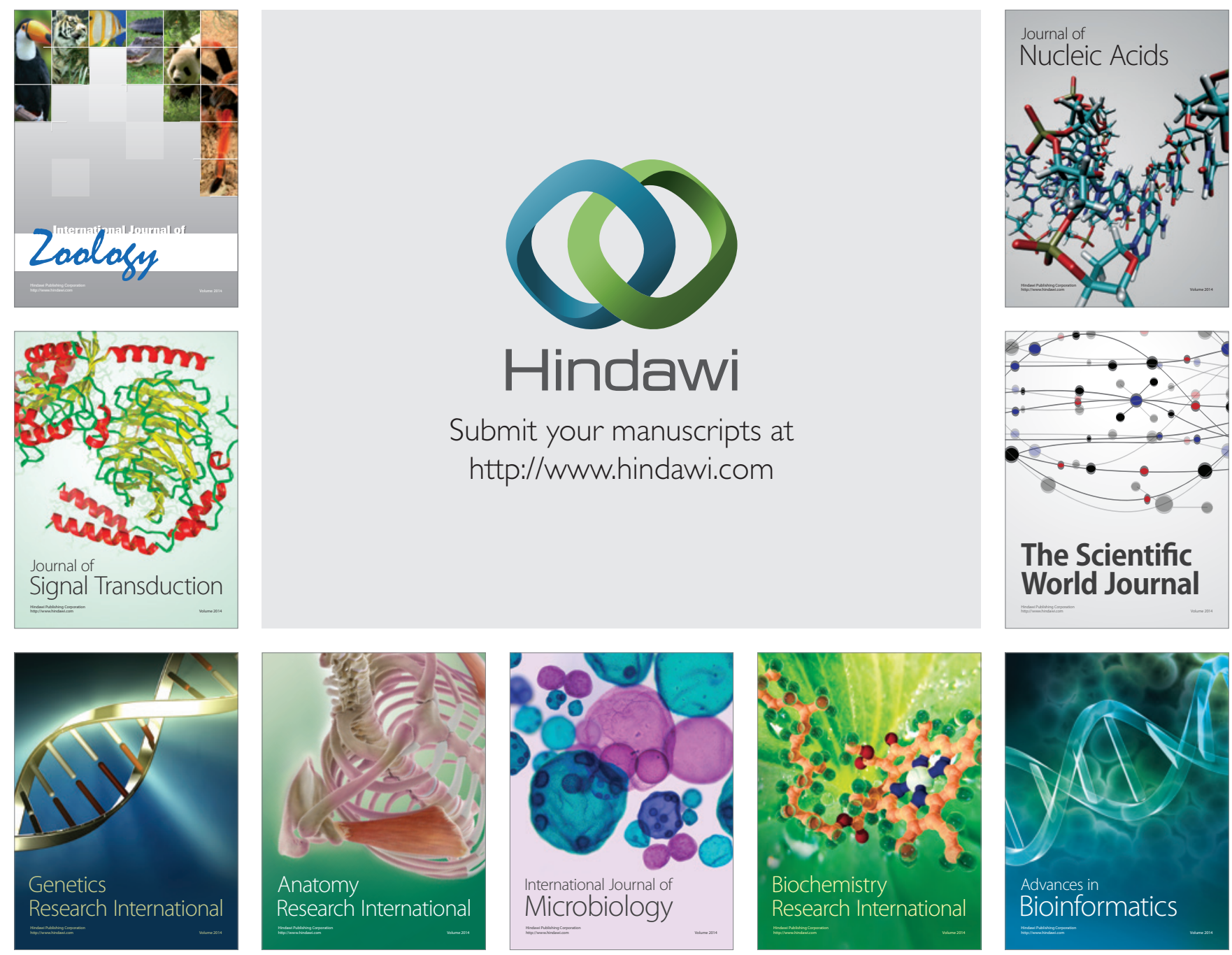

The Scientific World Journal
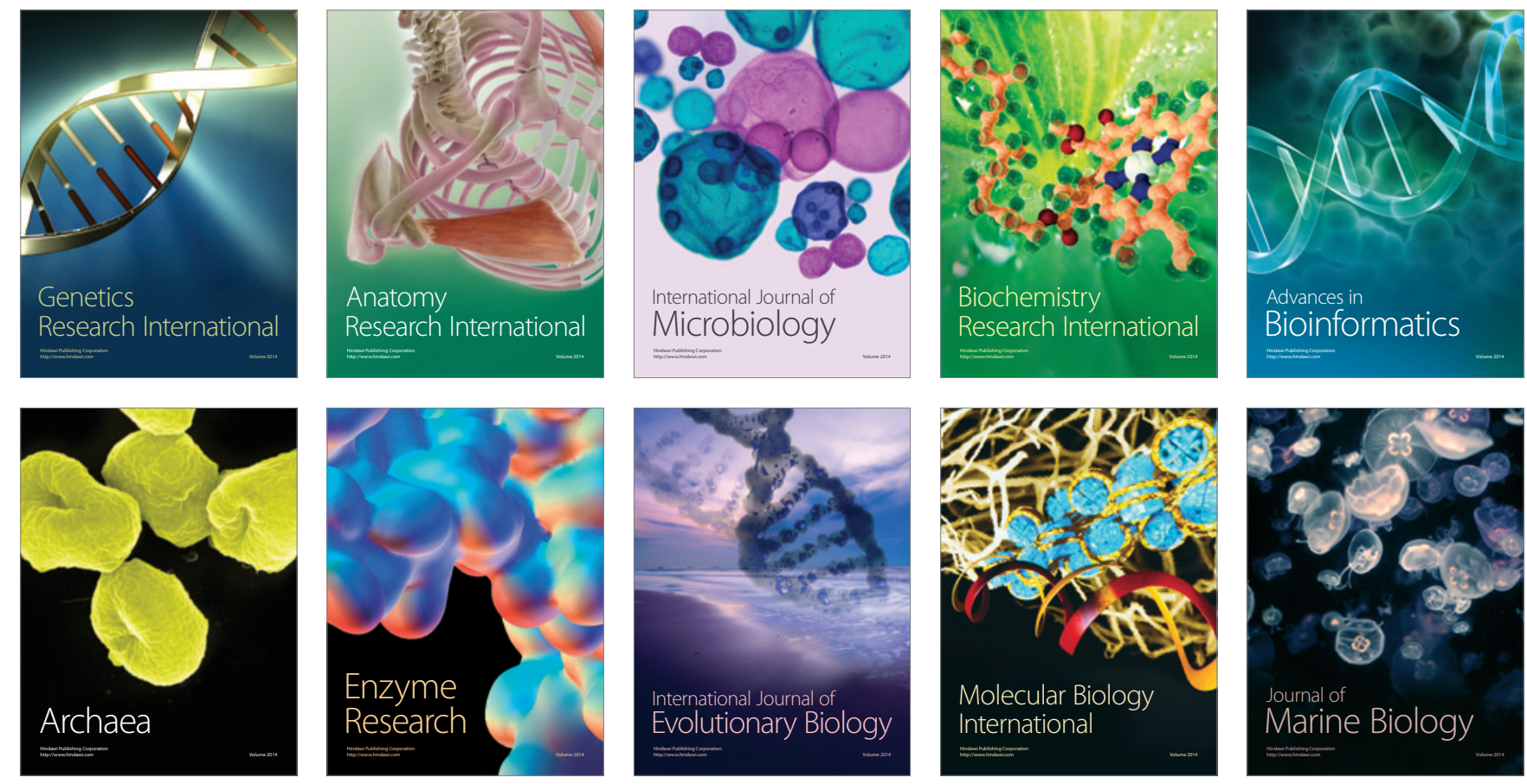